\title{
Simulated conservative tracer as a proxy for S-metolachlor concentration predictions compared to POCIS measurements in Arcachon Bay
}

\author{
Fauvelle Vincent ${ }^{1,{ }^{*}}$, Belles Angel ${ }^{2}$, Budzinski Hélène ${ }^{3}$, Mazzella Nicolas ${ }^{4}$, Plus Martin ${ }^{5}$
}

${ }^{1}$ Aix-Marseille Univ., Université de Toulon, CNRS, IRD, M I O, Marseille, France

${ }^{2}$ MINES ParisTech, PSL Research University, Geosciences - Centre for Geosciences and Geoengineering, 35 rue St. Honoré, Fontainebleau, France

${ }^{3}$ Univ. Bordeaux, UMR EPOC CNRS 5805, LPTC, Talence, France

${ }^{4}$ Irstea, UR EABX, 50 avenue de Verdun, Cestas, France

${ }^{5}$ Ifremer, Laboratoire d'écologie pélagique (DYNECO-PELAGOS), Plouzané, France

*Corresponding author : Vincent Fauvelle, email address : fauvellevincent@gmail.com

\begin{abstract}
:
The work presented here aims at comparing monitoring of S-metolachlor, the major pesticide in use in the Arcachon Bay (South West of France, transitional coastal area), by chemical analysis (monthly passive sampling) and contaminant dissipation modeling from sources (Mars-2D model). The global strategy consisted in i) identifying the major sources of S-metolachlor to the Bay, ii) monitoring these sources for 12 months, and iii) comparing modeled data in the Bay based on measured inputs, to chemical measurements made inside the Bay along with the 12-month source monitoring. Results first showed that the major S-metolachlor surface inputs to the Arcachon Bay are mainly from one single source. Modeled and measured data were in good agreement at 5 sites in the Bay, both in terms of concentration range and seasonal trends. Modeling thus offers a cost-effective solution for monitoring contaminants in transitional waters, overcoming in addition the technical limitations for measuring pg L-1 or lower levels in coastal waters. However, we highlighted that secondary sources may affect accuracy at local level.
\end{abstract}




\section{Graphical abstract}

Simulated S-metolachlor concentrations ( $n g$ L-1) in the Arcachon Bay surface seawater the 02/11/2011.

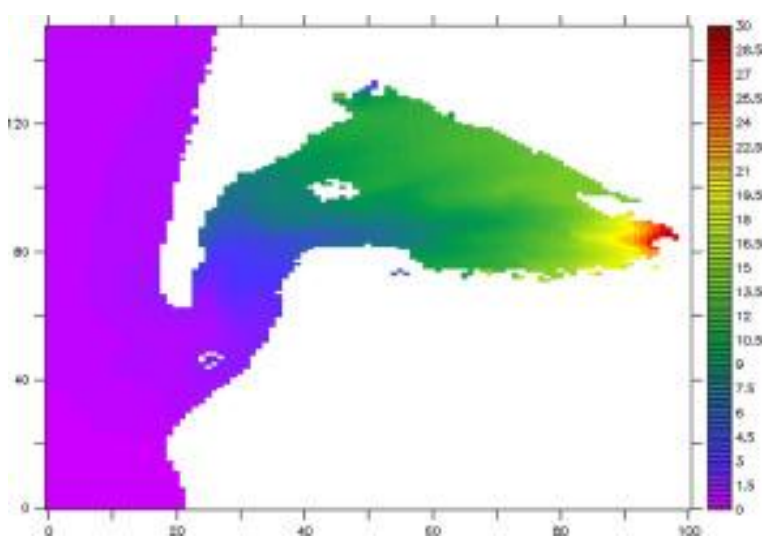

\section{Highlights}

- S-metolachlor concentration was modeled in the Arcachon Bay using MARS-2D. S S-metolachlor originated mainly from one single source. Chemical measurements were in agreement with modeled data

Keywords : Passive sampling, POCIS, Mars-2D, Contaminant, Monitoring, Coastal area, Pesticides, Smetolachlor 
The need for monitoring tools in natural water increases with regulation (Allan et al., 2006, Poulier et al., 2014). However, monitoring networks are often expensive when they aim at covering the entire area of interest. Among the targeted organic contaminants, pesticides are largely represented in priority pollutant lists because of their toxicity and ubiquitous presence (e.g., half of the Water Framework Directive, 2000/60/EC). Remarkably, herbicides exhibit the highest sales volumes (e.g., glyphosate, S-metolachlor), and are thus quantified in surface waters at higher levels than other pesticides (Comoretto et al., 2007). These substances may reach coastal water from freshwater inputs and affect organisms that were not initially targeted. For example, measurable biological effect of S-metolachlor on marine organisms vary between levels higher than $\mathrm{mg} \mathrm{L}^{-1}$ for microalgae growth, photosynthetic efficiency or lipid content (Ebenezer et al., 2013; Coquillé et al., 2018), to environmentally realistic sub $\mu \mathrm{g} \mathrm{L}^{-1}$ levels causing spermio and embryotoxicity on Crassostrea gigas (Mai et al., 2013). Passive sampling is increasingly developed for a wide range of contaminants, because it provides more accurate data, e.g., time-weighted average concentrations, freely dissolved contamination fraction, high preconcentration rates decreasing limits of detection (LD). It offers attractive advantages when considering how challenging surface water (and coastal water more importantly) monitoring is, due to high concentration variability over time and analytical difficulties inherent to trace level measurements in complex matrices. The Polar Organic Chemical Integrative Sampler (POCIS) was introduced by Alvarez et al. (2004) for the sampling of medium polar and polar organic contaminants (e.g., pesticides, pharmaceuticals), and is therefore a sampler of choice for the study of emerging pesticides, although recent developments tend to improve the quantitative ability of such adsorption based passive samplers (Chen et al., 2013; Belles et al., 2017, Fauvelle et al., 2017). 
52 The work presented here aims at monitoring S-metolachlor with POCIS in the Arcachon Bay

53

54

55

56

57

58

59

60

61

62

\subsection{Sampling and chemical analysis}

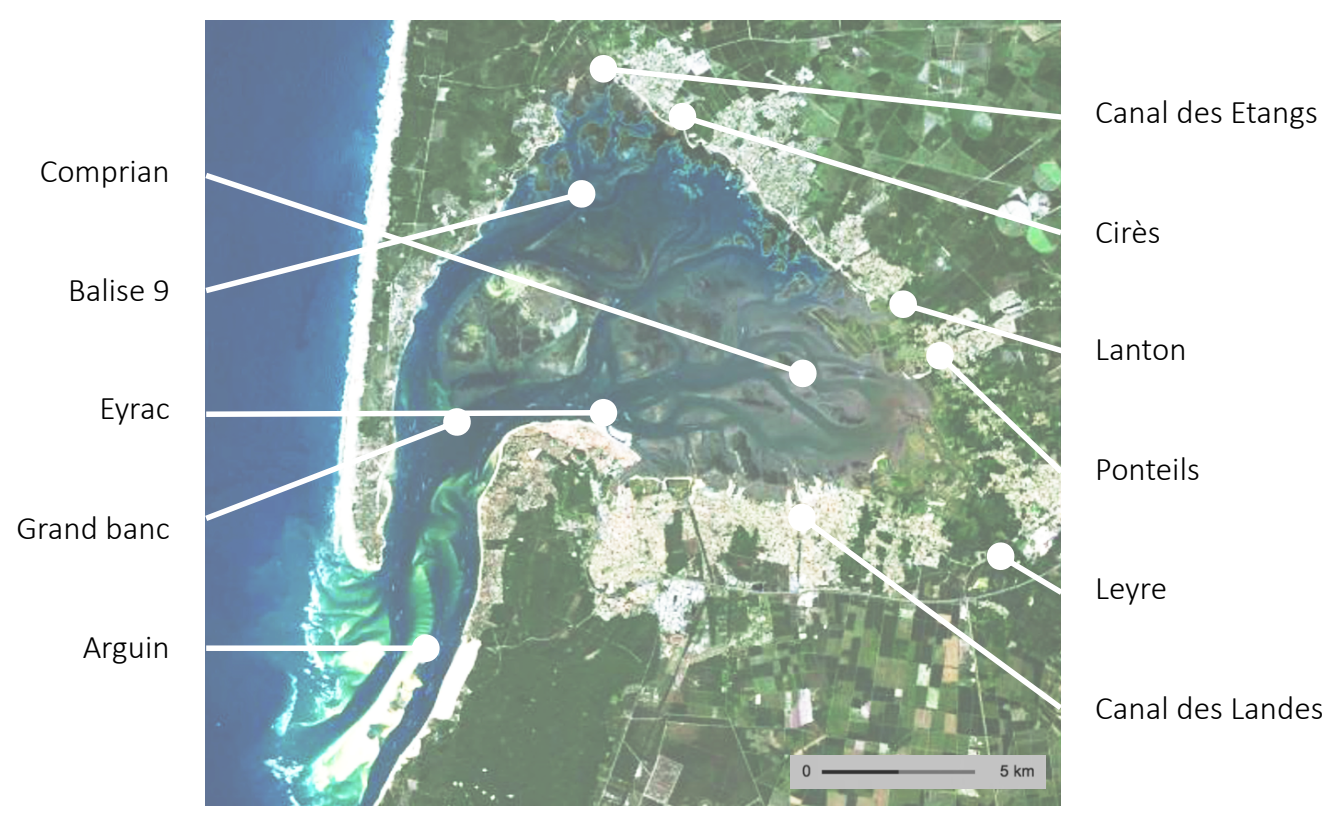
and its main tributaries, in order to get a comprehensive overview of sources and transfer from freshwater to seawater. Contamination modeling using Mars-2D (2-dimensions Hydrodynamical Model for Applications at Regional Scale) adapted to Arcachon Bay (Plus et al., 2009) is also assessed as a monitoring tool. The monitoring strategy we propose is based on three consecutive steps, i) preliminary mapping for sources identification during 4 months $(03 / 22 / 2010$ to $07 / 17 / 2010)$, ii) actual monitoring of the sources and the Bay by POCIS for the consecutive 12 months $(07 / 17 / 2010$ to $07 / 21 / 2011)$, iii) comparing MARS-2D modeled data from sources inside the Bay to the chemical measurements.

\section{Methods}

64

Figure 1. Localization of tributaries (right list) and sampling stations inside the Arcachon Bay (left list). Map from French National Institute of Geographic and Forestry Information.

Arcachon Bay is a $180 \mathrm{~km}^{2}$ mesotidal lagoon on the South Atlantic coast of France $\left(44^{\circ} 40^{`} \mathrm{~N}\right.$, $\left.1^{\circ} 10^{\prime} \mathrm{W}\right)$, connected to the Ocean by a large channel allowing important seawater exchanges (average of $0.410^{12} \mathrm{~L}$ at each tide, i.e., $50 \%$ of the total volume). Its maximum depth in 
channels is $20 \mathrm{~m}$. The area supports several activities in the Bay itself or its watershed (e.g., oyster farming, agriculture, aquatic recreational activities) that present conflicts of practice, to some extent related to the water contamination induced by any of these activities (Gamain et al., 2017). Five sampling stations inside the Bay together with the six main tributaries were selected for monthly sampling (Fig. 1). All analytical procedures are described by Belles et al. (2014) for POCIS exposed inside the Bay, and by Fauvelle et al. (2012) for POCIS exposed in the Bay tributaries. As S-metolachlor is exclusively used for agricultural purposes, we assumed that sources were located only at freshwater input sites. Therefore, the six main tributaries were selected in term of flowrate (Fig. 1, > $90 \%$ total river inputs, Auby et al., 1994) and monitored by POCIS immersed for four consecutive periods of 4 weeks from 03/22/2010 to 07/17/2010 for mapping the main sources of S-metolachlor to the Bay (Roubeix et al., 2012). Afterwards, 5 sampling stations inside the Bay (Fig. 1) together with the main sources previously identified were monitored the same way from $07 / 17 / 2010$ to $07 / 21 / 2011$ to perform the modeling exercise.

\subsection{MARS-2D model}

MARS is a hydrodynamical model that solves fluid mechanics equations commonly known as Navier- Stokes (Lazure and Dumas, 2008). This model has been previously applied to the Arcachon Bay (Plus et al., 2009), assuming the horizontal current does not vary significantly with depth and that the vertical current acceleration is negligible when compared to gravitational acceleration. Indeed, in this bay the water column is well-mixed all along the year, due to the strong tidal currents, the somewhat shallow depths and the low freshwater inputs when compared to the oscillating volume (Plus et al., 2009). The model geographical extension is $44^{\circ} 21-44^{\circ} 54 \mathrm{~N}$ and $0^{\circ} 57-1^{\circ} 27 \mathrm{~W}$, horizontal resolution is $235 \times 235 \mathrm{~m}$ (squared cells), and time step varies between 60 and 200 seconds. The model also accommodates with wet/dry zones and has been validated against tide gauges, acoustic Doppler current profiler and salinity measurements. The model used, at its open boundaries, a tide obtained from the Legos model 
94 (FES2004, Lyard et al., 2006; decimetric precision close to the coasts) and a meteorological

95

96

97

forcing obtained from the ARPEGE model (meteo France, Déqué and Piedelievre, 1995). In addition, the model incorporates pooled bathymetric data provided by L' Yavanc (L' Yavanc, 1995), the Gironde maritime navigation service and the Marine Hydrographic and Oceanographic Service (SHOM). For our purpose, it was hypothesized that i) vertical contaminant concentration heterogeneity is negligible, and ii) S-metolachlor is conservative (no degradation, no export to other compartments such as sediment or biota) under the environmental conditions of our study due to its high solubility and polarity (solubility $0.5 \mathrm{~g} \mathrm{~L}^{-}$ ${ }^{1}, \log K_{\mathrm{ow}}=3.1$ ). The model goodness-of-fit (observed vs. predicted values) on the variable 'Salinity' gives a good idea on the capacity of the model to reproduce passive tracer concentrations in the bay: the calculated root mean squared deviation of simulated salinity is 2.25, which corresponds to a 7.4\% error on average (Plus et al., 2009).

\section{Results and discussion}

\subsection{Identification and monitoring of sources}

Table 1. S-metolachlor concentration $\left(\mathrm{ng} \mathrm{L}^{-1}\right)$ in the main tributaries of Arcachon Bay measured by POCIS over the preliminary contamination mapping period (03/22/2010 to 07/17/2010). Method relative standard deviation is $23 \%$ and limit of detection (LD) is considered $1.5 \mathrm{ng} \mathrm{L}^{-}$ ${ }^{1}$ for POCIS exposed for 1 month in freshwater (Lissalde et al., 2011). Tributaries flow data are from Auby et al., 1994 over the 1989-1993 period

\begin{tabular}{ccccccccc}
\hline \multicolumn{2}{c}{ Sampler exposure period } & Unit & Leyre & $\begin{array}{c}\text { Canal des } \\
\text { Etangs }\end{array}$ & $\begin{array}{c}\text { Canal des } \\
\text { Landes }\end{array}$ & Cirès & Lanton & Ponteils \\
\hline $03 / 22 / 2010$ & $04 / 19 / 2010$ & ng L $^{-1}$ & 44 & 7 & 19 & 43 & 63 & $<$ LD \\
$04 / 19 / 2010$ & $05 / 17 / 2010$ & ng L $^{-1}$ & 51 & $<\mathrm{LD}$ & 16 & 97 & 148 & $<$ LD \\
$05 / 17 / 2010$ & $06 / 17 / 2010$ & $\mathrm{ng} \mathrm{L}^{-1}$ & 139 & $<\mathrm{LD}$ & $<\mathrm{LD}$ & $<\mathrm{LD}$ & $<\mathrm{LD}$ & $<\mathrm{LD}$ \\
$06 / 17 / 2010$ & $07 / 17 / 2010$ & $\mathrm{ng} \mathrm{L}^{-1}$ & 27 & $<\mathrm{LD}$ & $<\mathrm{LD}$ & 30 & 105 & $<\mathrm{LD}$ \\
\multicolumn{2}{l}{ Stream flow / Leyre flow } & - & 1.0 & 0.26 & 0.03 & 0.04 & 0.02 & 0.02 \\
\hline
\end{tabular}

Leyre river was found to be the main provider of S-metolachlor to the Bay over the preliminary concentration mapping step (03/22/2010 to $07 / 17 / 2010$, Table 1$)$. It had by far the highest flow 
and was the most contaminated sites (Table 1). Thus, it was considered thereafter as the only source of S-metolachlor to the Bay, i.e., only the Leyre river inputs were considered in MARS2D model. S-metolachlor concentration in the Leyre river was then measured in the range of $10-80 \mathrm{ng} \mathrm{L}^{-1}$ during the actual modeling exercise (07/17/2010 to $07 / 21 / 2011$, Fig. 2). The maximum concentration in this tributary occurred together with the maximum stream flow, resulting in an estimated massive flux of S-metolachlor towards the Bay during winter time (up to an average of $200 \mathrm{~g} \mathrm{day}^{-1}$ over the $11 / 30 / 2010-01 / 02 / 2011$ period). This major flux was grown by the unconventional rainfall behavior in 2010 (twice higher rainfall in November compared to the seasonal norms). Linking this $200 \mathrm{~g} \mathrm{day}^{-1} \mathrm{~S}-$ metolachlor flux to the total volume $\left(\sim 0.810^{12} \mathrm{~L}\right)$ and the residence time of freshwater in the Bay $\left(10\right.$ days for $120 \mathrm{~m}^{3} \mathrm{~s}^{-1}$ and 24 days for $10 \mathrm{~m}^{3} \mathrm{~s}^{-1}$ freshwater flow, De Wit et al., 2005, extrapolated to 22 days in our case, with a maximum flow of $28 \mathrm{~m}^{3} \mathrm{~s}^{-1}$ in November 2010, Fig. 2), we can roughly estimate a maximum averaged S-metolachlor concentration inside the Bay of $5 \mathrm{ng} \mathrm{L}^{-1}$. It is interesting to note that the maximum stream concentration measured in winter does not match the Smetolachlor application period, generally occurring in April-May for maize cultivation in this area. This finding suggests an unconventional fate of S-metolachlor from field application to its transfer to the receptive river. Indeed, because of the permeability of the sandy soils of the watershed surrounding the Arcachon Bay, the watercourses are more comparable to groundwater drains than to receptacles of the runoff water (Rimmelin et al., 1998). Therefore, the lag time observed in river contamination could be attributed to a temporary contaminant storage in superficial groundwater prior to discharge in rivers when groundwater table level is high enough to be drained by the neighboring river. 


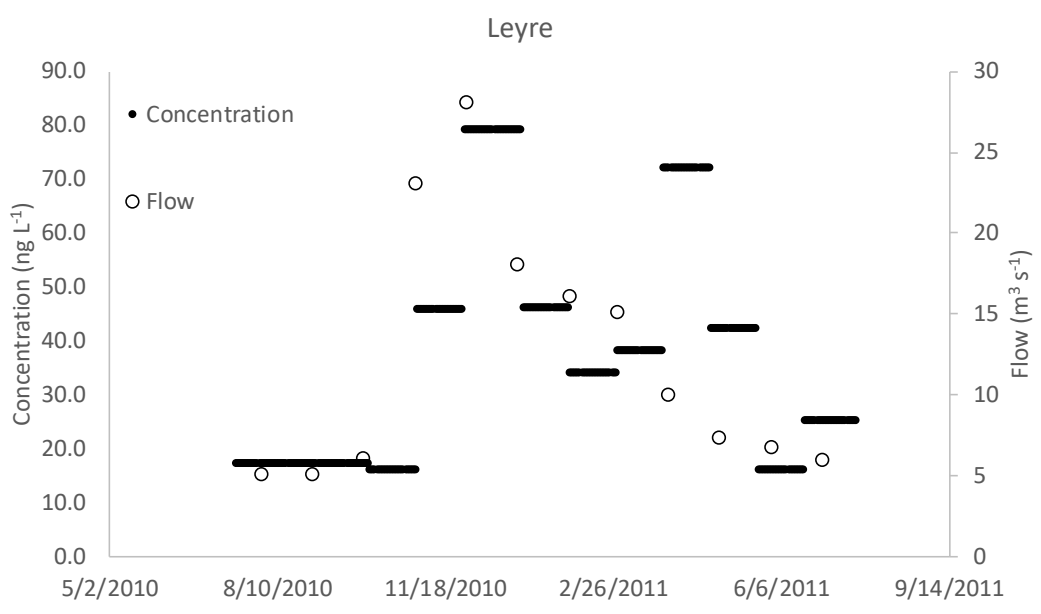

139 Figure 2. Concentration of S-metolachlor and flow of Leyre river over the modeling exercise 140 period (07/17/2010 to 07/21/2011). Method relative standard deviation is $23 \%$ and LD is 141 considered $1.5 \mathrm{ng} \mathrm{L}^{-1}$ for POCIS exposed for 1 month in freshwater (Lissalde et al., 2011). 

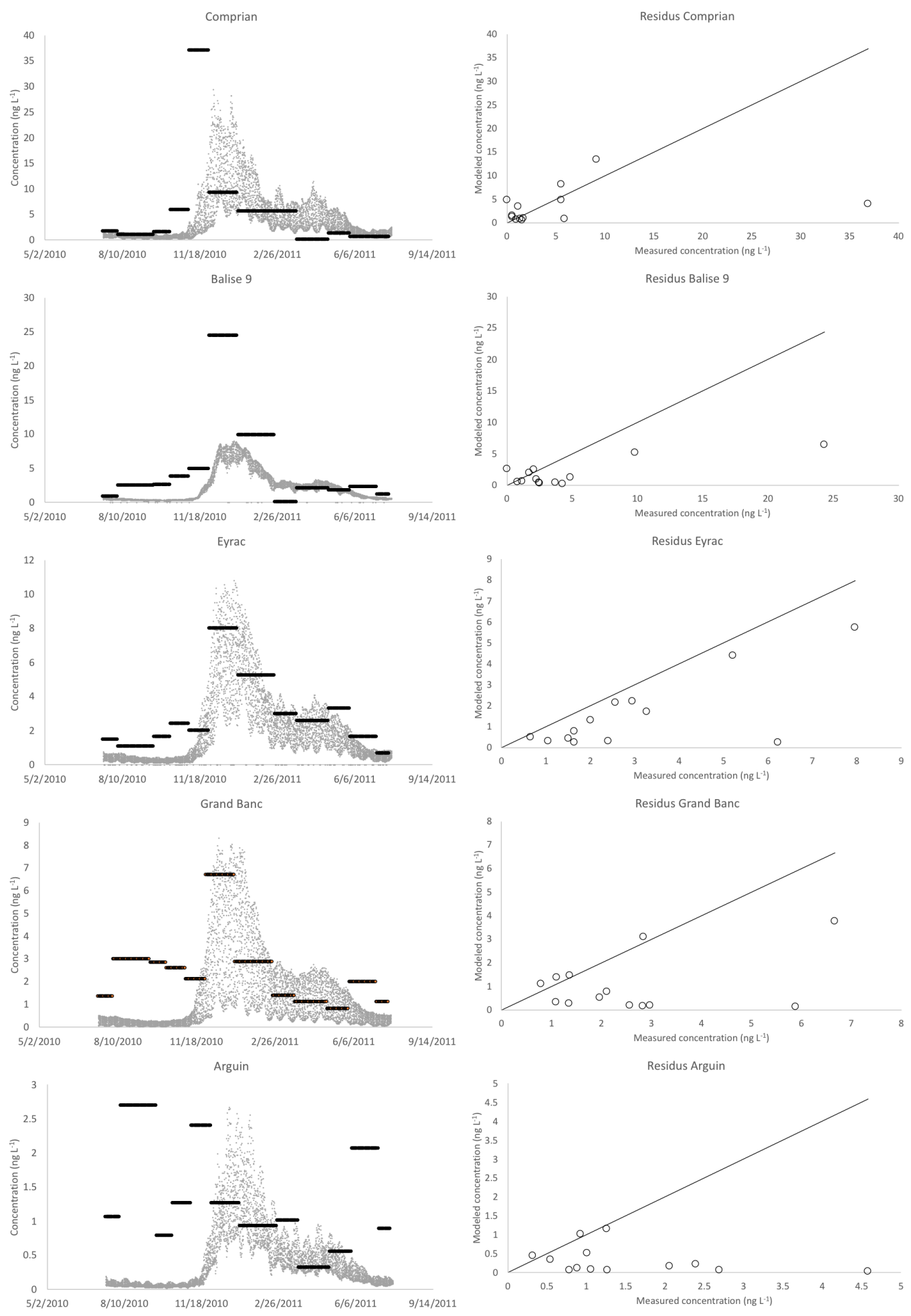

145 Figure 3. Modeled (grey dots) versus measured (black horizontal bars) concentrations inside the Arcachon Bay over the modeling exercise period (07/17/2010 to 07/21/2011). Concentrations were measured by POCIS, so horizontal bars represent monthly time weighted averaged concentrations (TWACs). Residues are based on averaged modeled concentrations versus POCIS TWACs. Mind different $\mathrm{Y}$-axis scales for concentration versus time plots. 
The modeled data inside the Bay at different points were in good agreement with measured concentrations (Fig. 3) both in terms of concentration range and seasonal trend. The maximum concentrations modeled at the 5 sites are also in the range of that estimated roughly in the previous section (i.e., $5 \mathrm{ng} \mathrm{L}^{-1}$ ). The dilution gradient between the source (Leyre, Fig. 1) and the open water (Arguin, Fig. 1) is also well represented by the modeled data at the various sampling stations. Data measured at Arguin site suffer from high dispersion, in relation with low levels quantified, close to LD. Although modeled and measured trends are roughly similar, we obtained an almost systematic underestimation of data modeled compared to the one measured. As highlighted in section 3.1, groundwater is probably a crucial compartment for contaminants fate. Deborde et al. (2008) showed that groundwater inputs to the Bay are between 2.7 and $5.3 \%$ of the rivers freshwater inputs, which could be negligible at the global scale, but might be of importance at the local scale. Unfortunately, we don't have any chemical monitoring of groundwaters around the Bay to discuss this hypothesis in more details. Moreover, the substantial underestimation observed at Balise 9 might highlight a secondary source on the northern side of the Bay. Canal des Etangs has a significant flow (26\% that of Leyre, Table 1) and might affect S-metolachlor concentration at Balise 9, but the concentrations found at that site were $<$ LD most of the time, with occasional detection at levels always below $7 \mathrm{ng} \mathrm{L} \mathrm{L}^{-1}$. Other issues could arise when trying to implement such an approach for more could be of importance, since most of the oyster farms are located close to the Leyre river mouth where S-metolachlor concentrations are the highest, eventually implying spermio and embryotoxicity. 
174 Thus, the model outputs have to be considered with caution despite their ability to predict 175 concentrations ranges and seasonal trends, in good agreement with measurements at different 176 points of the Bay. In fact, we speculate the need for more complexity in the behavior modeling 177 of the simulated tracer as well as for more accuracy in the estimation of sources. This type of 178 monitoring strategy would however be of interest given the drastic reduction of analytical costs 179 both in terms of number of samples required, and analytical challenges for quantifying low pg $180 \mathrm{~L}^{-1}$ levels. In addition, it offers the opportunity to get a comprehensive and high spatial 181 resolution overview of contaminants dispersion. 
182

183

184

185

186

187

188

189

190

191

192

193

194

195

196

197

198

199

200

201

202

203

204

205

206

207

208

209

210

211

212

213

214

215

216

217

\section{Acknowledgements}

The authors are grateful to the Region Aquitaine (OSQUAR project), and FEDER (OSQUAR project) and ANR Ripost for financial support.

\section{References}

Allan, I.J., Vrana, B., Greenwood, R., Mills, G.A., Roig, B., Gonzalez, C., 2006. A "toolbox" for biological and chemical monitoring requirements for the European Union's Water Framework Directive. Talanta 69, 302-22.

Alvarez, D.A., Petty, J.D., Huckins, J.N., Jones-Lepp, T.L., Getting, D.T., Goddard, J.P., Manahan, S.E., 2004. Development of a passive, in situ, integrative sampler for hydrophilic organic contaminants in aquatic environments. Environ. Toxicol. Chem. 23, 1640-1648.

Auby, I., Manaud, F., Maurer, D., Trut, G., 1994. Etude de la proliferation des algues vertes dans le Bassin d'Arcachon. IFREMER internal report, Arcachon, p. 275.

Belles, A., Pardon, P., Budzinski, H., 2014. Development of an adapted version of polar organic chemical integrative samplers (POCIS-Nylon). Anal. Bioanal. Chem. 406, 1099-1110.

Belles, A., Alary, C., Aminot, Y., Readman, J.W., Franke, C., 2017. Calibration and response of an agarose gel based passive sampler to record short pulses of aquatic organic pollutants. Talanta 165, 1-9.

Chen, C.-E., Zhang, H., Ying, G.-G., Jones, K.C., 2013. Evidence and recommendations to support the use of a novel passive water sampler to quantify antibiotics in wastewaters. Environ. Sci. Technol. 47, 13587-13593.

Comoretto, L., Arfib, B., Chiron, S., 2007. Pesticides in the Rhône river delta (France): basic data for a field-based exposure assessment. Sci. Total Environ. 380, 124-132.

Coquillé, N., Ménard, D., Rouxel, J., Dupraz, V., Eon, M., Pardon, P., Budzinski, H., Morin, S., Palranti, E., Stachowski-Haberkorn, S., 2018. The influence of natural dissolved organic matter on herbicide toxicity to marine microalgae is species-dependent. Aqua. Toxicol. 198, 103-117.

De Wit, R., Leibreich, J., Vernier, F., Delmas, F., Beuffe, H., Maison, P., Chossat, J.-C., Laplace-Treyture, C., Laplana, R., Clavé, V., Torre, M., Auby, I., Trut, G., Maurer, D., Capdeville, P., 2005. Relationship between land-use in the agro-forestry system of les Landes, nitrogen loading to and risk of macro-algal blooming in the Bassin d'Arcachon coastal lagoon (SW France). Estuar. Coast. Shelf Sci. 62, 453-465.

Deborde, J., Anschutz, P., Auby, I., Glé, C., Commarieu, M. V., Maurer, D., Abril, G., 2008. Role of tidal pumping on nutrient cycling in a temperate lagoon (Arcachon Bay, France). Mar. Chem. 109, 98-114.

Déqué, M. and J. P. Piedelievre (1995). "High resolution climate simulation over Europe." Climate Dynamics 11(6): 321-339. 
Directive 2000/60/EC of the European Parliament and of the Council of 23 October 2000 establishing a framework for Community action in the field of water policy, Off. J. Eur. Comm. L327 (2000) 1.

Ebenezer, V., Ki J.-S., 2013. Quantification of Toxic Effects of the Herbicide Metolachlor on Marine Microalgae Ditylum brightwellii (Bacillariophyceae), Prorocentrum minimum (Dinophyceae), and Tetraselmis suecica (Chlorophyceae). J. Microbiol. 51, 136-139.

Fauvelle, V., Mazzella, N., Delmas, F., Madarassou, K., Eon, M., Budzinski, H., 2012. Use of mixed-mode ion exchange sorbent for the passive sampling of organic acids by polar organic chemical integrative sampler (POCIS). Environ. Sci. Technol. 46, 13344-13353.

Fauvelle, V., Montero, N., Mueller, J.F., Banks, A., Mazzella, N., Kaserzon, S., 2017. Glyphosate and AMPA passive sampling in freshwater using a microporous polyethylene diffusion sampler. Chemosphere 188, 241-248.

Gamain, P., Feurtet-Mazel, A., Maury-Brachet, R., Auby, I., Pierron, F., Belles, A., Budzinski, H., Daffe, G., Gonzalez, P., 2017. Can pesticides, copper and seasonal water temperature explain the seagrass Zostera noltei decline in the Arcachon bay? Mar. Pollut. Bull. In press

L'Yavanc J., 1995. Evolutions bathymétrique et morphologique du bassin d'Arcachon. http://archimer.ifremer.fr/doc/00080/19127/

Lazure P., Dumas. F., 2008. An external-internal mode coupling for a 3D hydrodynamical model for applications at Regional Scale (MARS). Advances in Water Resources 31, 233250.

Lissalde, S., Mazzella, N., Fauvelle, V., Delmas, F., Mazellier, P., Legube, B., 2011. Liquid chromatography coupled with tandem mass spectrometry method for thirty-three pesticides in natural water and comparison of performance between classical solid phase extraction and passive sampling approaches. J. Chromatogr. A 1218, 1492- 1502.

Lyard F., Lefevre F., Letellier T., Francis O., 2006. Modelling the global ocean tides: modern insights from FES2004. Ocean Dynamics 56, 394-415.

Mai, H., Morin, B., Pardon, P., Gonzalez, P., Budzinski, H., \& Cachot, J., 2013. Environmental concentrations of irgarol, diuron and S-metolachlor induce deleterious effects on gametes and embryos of the Pacific oyster, Crassostrea gigas. Mar. Environ. Res. 89, 1-8.

Plus, M., Dumas, F., Stanisière, J.-Y., Maurer, D., 2009. Hydrodynamic characterization of the Arcachon Bay, using model-derived descriptors. Cont. Shelf Res. 29, 1008-1013.

Poulier, G., Lissalde, S., Charriau, A., Buzier, R., Delmas, F., Gery, K., Moreira, A., Guibaud, G., Mazzella, N., 2014. Can POCIS be used in Water Framework Directive (2000/60/EC) monitoring networks? A study focusing on pesticides in a French agricultural watershed. Sci. Total Environ. 497-498, 282-292.

Rimmelin, P., Dumon, J. C., Maneux, E., Gonçalves, A., 1998. Study of annual and seasonal dissolved inorganic nitrogen inputs into the Arcachon Lagoon, Atlantic Coast (France). Estuar. Coast. Shelf Sci., 47, 649-659.

Roubeix, V., Fauvelle, V., Tison-Rosebery, J., Mazzella, N., Coste, M., Delmas, F., 2012. Assessing the impact of chloroacetanilide herbicides and their metabolites on periphyton in the Leyre River (SW France) via short term growth inhibition tests on autochthonous diatoms. J. Environ. Monit. 14, 1655-1663. 